\title{
The Teacher
}

\section{Textbooks, Technologies, and Tocqueville: Alternatives for Introductory American Government}

\author{
Reid Cushman, University of Virginia
}

... [T]he parallel between the occupations of graveyard attendant and custodian of learning was one which often suggested itself to others besides the students.

-Kingsley Amis, Lucky Jim

In a typical year of this decade, some 14 million students will occupy space in American colleges and universities. They will "produce" nearly 2 million degrees, three-quarters of them associates and bachelors. ${ }^{1}$ Only a small fraction of the latter output-well under 50,000-will be political science degrees per se. Yet when it comes time to schedule the introductory courses, particularly the American government survey, it sometimes seems the whole world doth contemplate a major in poli sci. Drawing on some combination of interest (arguably healthy in a democratic citizenry) and distributional requirements (as an ever-popular part of the curricular "core"), poli sci survey offerings are often filled to bursting. A glance at the APSA "want ads" shows that anyone who wants an academic slot must contemplate such teaching. Anyone who is remotely an Americanist (and many who are not) must contemplate teaching "Intro AG" in particular.

Based on publishers' estimates, in a typical year as many as 500,000 students may be exposed to fundamentals of the American system in a higher education setting. ${ }^{2}$ Students' expectations for this exposure are often not very high, since their prejudice is that the course only revisits what they learned in high school civics a year or two before. (Usually true; of course, most of them have forgotten most of what they learned then.) It doesn't tend to be an inspir- ing prospect for instructors either, who face teaching the same basic material, with minor variations, year after year. The only consistent excitement may come to department heads, who better stand to justify budget and position requests with the volume of credit hours so generated. (Not to mention that, under certain capitated reimbursement schemes, departments can make a fortune on these classes in their own right.)

Worthwhile or not, inspiring or not, the mass demand for surveys like Intro AG remains. Under current production technologies, that demand is most likely to be met in the large lecture class, typically in conjunction with large, fact-filled textbooks. New tools, like computerbased interactive media, may well point to a better way of learning for the future; for now, though, their price is well beyond most budgets. Lesser revitalization, within the constraints of the lecture hall, may also be provided on the cheap: using now-mundane technologies like overheads, slides, and videotapes. Even cheaper, but rather more perilous, is occasionally to remove the expensive textbook itself as the centerpiece of the class, and supplant it with a "real" book or two. Textbook publisher representatives, as well as a few senior colleagues, may in fits of candor say that only new, naive professors will consider this seriouslyattempting graduate-school teaching methods entirely inappropriate to younger and blanker minds. But after a year and a half of experimentation with Alexis de Tocqueville's Democracy in America as my main text for Intro AG, I am not yet convinced such ventures are mistakes.

\section{Tocqueville's Perspective}

Most persons put in the position of teaching political science classes have been exposed to Tocqueville's classic at some point in their education. Like many classics, whether read, skimmed, or learned via anthology or borrowed notes, the memory of it is often a mixed one. Even those willing to grant its deserved fame probably remember it as rather long, at times tedious, and, although it is unscholarly to say so, bordering on boring. Moreover, having been written by a Dead Western White Male, it is exactly the kind of politically incorrect selection that nowadays can cause dust-ups at faculty gatherings. Who needs the aggravation? But Tocqueville can be worth the risks, and in part precisely because it seems such an unlikely candidate: Democracy has the potential to demonstrate to students (not to mention instructors) the claims to enduring relevance often made casually for "great books," but rarely tested by actual prominence in syllabi.

Political philosophers, whose reading selections have long emphasized the long dead (although now more female and less Western if possible), may have fewer problems with this proposal. They assign "real books" as a matter of course. But other types of political scientists, however polite about it, are likely to be as skeptical as their students about the pertinence of 150-year-old observations to current American institutions and practices. Many, if not most, social scientists seem to have adopted some variant of a "currency" paradigm popular with economists: things 
written more than a few decades past get relegated to the realm of interesting anecdote. Yet a Tocqueville, no less than a Smith, Ricardo, or Keynes, ${ }^{3}$ still has much to offer. Indeed, what is so striking about reading Democracy is the dead-on accuracy of the observations. For all the surface differences, neither the content of the American character, nor the core problems of American democratic governance, seem to have changed. Perhaps this is why the book is still endlessly quoted, ${ }^{4}$ whether read or not.

Tocqueville is at his best articulating the central conflicts of democratic political theory: the fundamental tensions between liberty and equality, the pull of individualism against the needs of community, the difficulty of bringing wisdom to a system where the masses are empowered. Preoccupied with equality, and unequivocally convinced of its inevitability, Tocqueville nonetheless orients his observations from the then-respectable (but to modern students wholly foreign) perspective of aristocracy. It is this perceptual distance that gives Democracy its "bite," and sets its analysis of American institutions above the dry renderings of many modern textbooks. In Democracy, students can find passages that still resonate as descriptions of the society they inhabit. There are assertions they find complimentary and comforting; and there are some that they find deeply disturbing, such as Tocqueville's contention that democracies are ever ready to sacrifice liberty in pursuit of greater equality, and that citizens in them are prone to mindnumbing conformity.

Democracy does cover the institutional basics, from the details of the national government down to the operation of the lowliest township. But Tocqueville's greater preoccupation is with the culture and mores of the people who function within those structures. (Thus, for example, the chapter on the "Future of the Three Races"-viz, Indian, Black, and White--is longer than the one on the "Federal Constitution.") Students, accustomed to believe in the almost magical aspects of the American structure, are challenged by the notion that maybe the "habits of the heart" more than the shape of the organization charts are what really count. (These "values" issues have become a preoccupation of late, and Tocqueville's discussions provide a neat tie to current political discourse.) Insofar as Democracy ends up making the Federalist institutional case, it does so from the more distinctively anti-Federalist ground of character. It thus makes a perfect counterpoint to an institutionally preoccupied textbook, or to one which

\section{Tocqueville is at his best articulating the central conflicts of democratic political theory: the fundamental tensions between liberty and equality, the pull of individualism against the needs of community, the difficulty of bringing wisdom to a system where} the masses are

\section{empowered.}

gives the serious arguments of the system's critics. only limited play. ${ }^{5}$

\section{Textbooks vs. Tocqueville}

Granting that these Tocquevillean issues are important (and maybe even interesting), couldn't most of it wait until, say, the American Political Theory class? Shouldn't it wait until we are sure that students have a proper foundation for it? Indeed, survey courses as usually conceived are preeminently concerned with conveying a core of "basic facts," on which foundation upper-level courses may later build. Detail-filled, oughtto-be-sold-by-the-pound textbooks are certainly written to this norm, and typically perform the job quite adequately. But however impressive the range and quality of current offerings, ${ }^{6}$ there is unfortunately little evidence that a large fraction of particulars remain in student brains any longer in college than they did in high school. Upper-level courses still must spend a lot of time recapitulating what students successfully regurgitated as recently as the previous semester. One may argue that at least the prior fact exposure prepared neutral pathways for subsequent resurfacing. But one might also assert that students would be as well served if more complex themes could be addressed, even at the expense of some minutiae. Particularly if those themes are such as to generate a little passion.

Instructors sometimes seem to forget that another function of the introductory survey is to build enough interest to make students want to get the greater detail the upper-level courses provide. Granting textbooks many virtues, few would say they are prone to ignite interest in the subject. Too often they seem designed to stop it dead in its tracks. This is a virtue only if introductory classes are viewed as "weeders," serving to eliminate all but the talented and the true believers. Furthermore, unless a watered down version (a sort of "American Government for Poets") is to be offered, the introduction must still serve students for whom the subject matter is only an academic sidelight, rather than a way of life. Critics will say it is these sojourners who especially need a textbook. As one colleague put it: "You've got only one semester to straighten them out for the rest of their lives." But if that be true, is it better to spend more time on the great issues of liberty and equality, as they are played out within the American system, or more on how the House Rules Committee works?

To be sure, it is not that most textbooks fail to address important themes, but rather that the themes often lose visibility in the forest of detail accompanying them. Moreover, students and instructors alike understand it is easier to test for the memorization of concrete facts and factoids on exams, particularly if the scale of the class (or the instructor's disposition, should graders be unavailable) precludes a lengthy essay test. Both sides accordingly turn to the boldface terms and chapter summary bullets come multiple-guess 
examination time. Granted, instructors are free to address the grander themes in lecture. Indeed, adding coherence and an overall structure to the jumble of information is a principal function of these gatherings. But lectures in large classes rarely can stray far from the structural foundation afforded by the central readings. Each must reinforce the other precisely because there is so little intimate student-instructor contact to help clarify ideas. Thus the text's structure more often than not defines the course.

The addition of a non-textbook book, such as the classic Federalist Papers (e.g., Rossiter 1988), is already a standard response to this difficulty. Notably ambitious instructors will even counterpoint Madison et al. with a collection of antiFederalist writings. But, unfortunately, such readings usually take a second seat to the textbook - which already provides more than enough bulk reading to fill a semester-and as a consequence are often read in a sporadic and limited fashion that attenuates the arguments. Textbooks generally render everything as blandly and evenhandedly as possible, to be sure no one is offended. Good for sales, perhaps, but lousy for promoting reader engagement. The Federalist and anti-Federalist cases incite interest precisely because each side stakes a real position, and only lengthy assignments give students an impression of their force and the continuing importance of the issues raised.

Only if the "supplemental" text is made as important as the textbook itself can the former's themes exert as much influence on the flow of the course. The Federalist is still certainly a possibility for this larger role, when complimented by anti-Federalist writings (e.g., Ketcham 1988; Storing 1981). Another possible "backbone"' is James Madison's wonderful Notes of Debates in the Federal Convention of 1787 (Madison 1987), with its day-by-day, blowby-blow accounting providing eloquent counterpoint to the usual presentation of the American system as somehow sprung fully formed from the heads of the borderline divine. ${ }^{7}$ Complimented by a decent textbook, either of these options will provide students with the institutional sweep. But since textbooks usually already deliver institutional emphasis, something with an alternative focusmore sociological, psychological, anthropological-may be a better bet. Hence, Tocqueville's Democracy in America. ${ }^{8}$

\section{Teaching Tocqueville}

It is axiomatic that one of the most important variables in any class -an absolutely critical one for a large lecture class-is the enthusiasm the instructor brings to the material.

\section{Students, accustomed to}

\section{believe in the almost}

magical aspects of the

American structure, are challenged by the notion that maybe the "habits of the heart" more than the shape of the organization charts are what really

\section{count.}

Rekindling that enthusiasm, almost inevitably worn down in the context of teaching the same material again and again, is one of the principal reasons for considering Tocqueville at all. Clearly, then, the first step is to (re)read Democracy to see if the claims made herein about its quality and currency hold up. If it seems as enervating now as it did before, there is no sense going any further; besides, you'll never sell it to students if you can't sell it to yourself. Although several editions are undoubtedly collecting dust in a nearby library, such an exploration is perhaps best conducted with the editions that students can purchase. Two paperback versions are currently available. The Lawrence-Mayer translation (Tocqueville 1988) is considered to be somewhat more accessible to modern readers, given its idiomatic style. It is also a bit cheaper than its rival, the two-volume ReeveBowen-Bradley translation (Tocque- ville 1990).

Selecting a textbook to pair with either of these is a little tougher, since there are quite a few good choices. It is probably preferable to avoid the larger models, since students will already be devoting a considerable number of pages to Tocqueville. Among the better of the shorter are the condensed Lowi and Ginsberg (1992) and Wasserman (1991). (Both are also very reasonably priced in paperback.) The latter is the more low-level, simply written text. Some would say too simple, but that may be an appropriate "reward" for students given the difficulty of the assignments in Democracy. Sticking with a familiar, if larger, textbook is also fine; but one must be willing to sharply cut back readings, and not every text lends itself to easy abridgement. (Big texts also tend to be expensive ones.) Not every page of Democracy need be read either, of course. Indeed, substantial omissions, particularly from volume two, are recommended. But covering enough of the book to convey the essential arguments will still translate into several hundred tough pages. $^{9}$

Though Democracy's brilliance may be striking to at least some instructors, it is surely less so to most students. Only a fraction are likely to have the maturity and background to handle large chunks of Tocqueville unassisted. Pacing the readings on a weekly basis, and going over a small segment each class, can encourage students to keep up. Besides noting the important points and most quotable quotes, these recapitulations are opportunities to tie the material to the "current"' events of Tocqueville's time, as well as to what is current from the student's perspective-i.e., things that have happened in the last three years. Such linkages are important to any teaching, but especially critical as part of selling the relevance of "some old book by some dead French guy" (as one of my students described it to his colleague). Background assistance in this regard probably requires access to a good American history text or two. The particular context of Tocqueville and his book is also quite useful, and painlessly offered by Jardin's superlative biography (1988). 
This alone adds up to a fairly ambitious survey" of American history and politics-more than enough material to fill a course. But exceptionally determined instructors can also delve a bit into political philosophy, setting Tocquevillean themes against the Madisonian model's assumptions, contrasting Federalist and anti-Federalist positions, comparing Platonic-Rousseauean visions to the liberal traditions out of Hobbes, Locke, et al., or even moving to modern collisions like that between Rawls and Nozick. ${ }^{10}$ The beauty of Democracy is that it lends itself to something this expansive, or to "simply" exploring basic themes like liberty and equality within the American political-historical context. To be sure, weaving these elements together into some sort of coherent progression constitutes the major challenge of the course. ${ }^{11}$ Indeed, it is the principal penalty born of rejecting the ready-made superstructure of a textbook. But even if the fit is not always perfect, students seem to be tolerant if they sense the instructor's commitment to teaching them something of lasting importance.

Assignments can help suggest the fit among otherwise disparate pieces, and reinforce the relevance of the issues raised. In short papers, students can be asked to compare and contrast a Tocquevillean quote with an excerpt from a recent newspaper or magazine piece. Longer papers can take a theme addressed at length in Democracy (e.g., race, gender relations) and contrast the book's rendering with current issues and perceptions. ${ }^{12}$ Students are thus forced to examine which, if any, of the book's insights into the 1830's United States transcend that particular era. Tocqueville placed great emphasis on America's decentralized governmental system, and the opportunity it offered for relating the individual to his community. Student reports on political activities back in their home states and localities are thus particularly appropriate (and particularly complimentary to textbooks that stress national institutions). Participation as a volunteer in some form of community service (and reporting on it for credit), affords a concrete way for students to explore the more private, nongovernmental aspects of the relationship between individual and community. This too was a Tocquevillean obsession. (Aside from its relevance, this thousand-points-oflight assignment turns out to be one that students almost always find extremely fulfilling.) ${ }^{13}$

Any teaching experiment such as this requires thorough assessments of student learning. Performance on quizzes is an obvious source of such information; frequent quizzes allow this feedback to be gotten early and often. (Happily, learning theory suggests that multiple, small tests are preferable anyway.) Most grading software now allows thorough analy-

\section{To be sure, it is not that most textbooks fail to address important themes, but rather that the themes often lose visibility in the forest of detail accompanying them.}

sis of the patterns of responses on tests, identifying areas that need greater clarification or emphasis. Survey questions about the course can also be piggy-backed onto the quizzes (with some extra credit given for responses), rather than waiting for standard end-of-semester evaluations. Aside from identifying problem areas, such assessments seem to enhance student performance simply by demonstrating that the instructor truly cares if they are "getting it." (A species of Hawthorne effect, perhaps.) Assessment data can also be quite useful for responding to the concerns of faculty colleagues who are dubious about this teaching approach.

\section{Technology vs. Tocqueville}

Almost anyone who has taught an amphitheatre-filling subject is aware of the commercial interest such large markets engender: an avalanche of publisher samples, vying for selection, is guaranteed to clog the departmental mailbox for years to come. Mindful of the workload most professors face-particularly the overextended junior faculty often saddled with the introductory surveys -both publisher notices and the ever-friendly publisher representatives accompanying them increasingly tout both quality and convenience in these offerings. Textbooks now come matched to supplemental readers, study guides, instructor manuals, test blanks (already on diskette), sets of overheads and slides, videotapes, and so forth. Now that interactive video and computer multimedia equipment are becoming more common on campus, these tools are increasingly seen in the product bundle as well.

In the face of all this progress, it might seem that only a Luddite would advocate saddling a visually oriented generation with some dusty tome-a move backwards in more ways than one. But it should be noted that, for all the glitzy appeal, few experts really claim to know how much improvement these new teaching technologies actually purchase. A perusal of scholarly literature on the subject generally confirms a confession I heard given by a panelist at a recent conference on integrating computers into the college classroom:

"People ask if my students learn better now [with computers]. I don't know. But I really didn't know how well they were learning before either." ${ }^{14}$ (Statements like this make one glad education reformers have not yet focused past American high schools.) Pending the arrival of hard effectiveness data, low-tech experimenters need make few apologies, particularly in an environment where the high-tech tools are budgetarily unavailable anyhow.

Those that stick with a "real book" or two can also make a claim to advancing a type of learning well described by Bloom (whatever one thinks of his politics or his choice of pronouns): "He who has read one book well is in a position to read any book, while he for whom books are easy currency is rendered incapable of living fully with one." ${ }^{15}$ One of the happy surprises in teaching Tocqueville was the receptiveness of students to the approach, and the degree to which even students of modest talent (and considerable 
initial skepticism) responded to it. The unhappy surprise was the lack of enthusiasm from some colleagues: Americanists in particular were concerned that an important topic was being ill-addressed under this oddball approach. Such fears are surely legitimate, and speak again to the need for a thorough assessment effort regardless of the level of technology employed. But that requires a considered effort to define what we want to have students learn, rather than simply an assertion that only certain methods are correct to teach it. Too often the definition of some teaching performance standard is viewed as an assault.

One might hope, in more private moments, that technology will someday help subvert the lecture amphitheatre itself: computer-based, selfpaced, teacher-assisted learning replacing the inevitably passive and all-too-often soporific performance art environment of the large lecture class. ${ }^{16}$ Since the invention of the printing press, the only consistently good thing one can say about the lecture, in the hands of most instructors, is that it is still cheap. But for as long as this method of teaching must remain common, we can at least be open to all the approaches that may make it more productive. Use of better displays on the lecture hall wall is a fine step if it can be afforded, and if it truly compliments the material and the instructor's style. But there should also be room for low-tech approaches, for at least a while longer, in the name of making learning something a little less deadly for a few among the millions involved-on both sides of the lectern.

\section{Notes}

1. U.S. Department of Education, National Center for Education Statistics, Digest of Education Statistics (annual) and Projections of Education Statistics (annual). Statistics include junior or community colleges, regular "four-year" colleges, and graduate/professional schools.

2. At least that is the estimated size of the market for Intro AG textbooks, readers, etc.; informal publisher estimates of sales range from 300,000 to 800,000 . Such a market, though large, is not of the same scale as firsttier niches like introductory economics or psychology.

3. In contradistinction to usual practice, Buchholz (1989) does an excellent job of selling the insights of long-dead economists.

4. Witness former Texas Representative Barbara Jordan's use of Tocqueville on the subject of American women, in her keynote address to the Democratic National Convention on July 13, 1992. Jordan's excerpt suggested a rather more enlightened feminist stance than Democracy actually delivers.

5. See A. J. Eksterowicz and P. C. Cline, "Ratification of the Constitution: The Great Debate as Portrayed in American Government Textbooks," PS 24(2): 211-15.

6. At last count, there were over 20 hardback introductory American government texts in print, along with almost as many paperbacks.

7. Since the Notes cover a period of about four months, or approximately the length of a semester, they can be read on a day-by-day pace.

8. It is possible to teach without any textbook at all, of course, but this puts a considerable burden on instructors to develop coherent supplementary material. It is also difficult where students' "civics" preparation is particularly weak.

9. I assign 465 of 678 pages in the Lawrence-Mayer edition; approximately twothirds of this is from volume 1 .

10. Tocqueville's notion of "self interest rightly understood," akin to the "enlightened self interest" of Madison et al., can also be explored particularly well using rational choice theory.

11. Evidence from cognitive psychologists suggests that students can focus on one lecture topic for at most 15-20 minutes at a time. Modularization of lectures into subunits is one response to this ostensible limit (e.g., spending a segment on the day's Democracy readings, then on the material from the textbook, and perhaps a last unit on whatever political-economic-historicalcultural-philosophical topic seems pertinent).

12. These larger papers can be written individually, or in groups. Group papers are often of higher quality, yield practice on interpersonal skills of value in their own right, and, of course, reduce the number of papers to be graded. However, fairness in grading usually requires some system of anonymous intra-group assessment to attenuate free-rider problems, which can be an administrative burden.

13. Ideally, instructors will build flexibility into the system of assignments-permitting a range of combinations of quizzes and other assignments to let each student work at what he or she does best. Unfortunately, building an aggregate score from a variable (and variably weighted) bundle of assignments for each student is beyond most grading software. It is, however, easily done with a pro- grammable statistical package like SPSS.

14. See, e.g., R. B. Kozma and J. Johnston, "The Technological Revolution Comes to the Classroom" (Change, January/February 1991: 10-12) for an upbeat portrayal of the possibilities, which nonetheless admits to the real dearth of assessment data.

15. Quoted in "Revise, Revise," The New Republic, 28 January 1991.

16. Alternatively, the technology may merely be used to replicate the old approaches: the first "Classroom of the 21st Century" at a nearby institution is essentially a wired version of the large lecture hall, complete with a wall-sized display for multimedia exposure en masse, and multiple-choice response keypads at every student seat.

\section{References}

Buchholz, Todd G. 1989. New Ideas from Dead Economists. New York: Penguin Plume.

Jardin, Andre. 1988. Tocqueville: A Biography. Trans. Lydia Davis and Robert Hemenway. New York: Farrar, Straus and Giroux.

Ketcham, Ralph, ed, 1988. The AntiFederalist Papers and the Constitutional Convention Debates. New York: Penguin Mentor.

Lowi, Theodore J., and Benjamin Ginsberg. 1992. American Government, brief 2 nd ed. New York: W. W. Norton.

Madison, James. 1987. Notes of Debates in the Federal Convention of 1787, Bicentennial ed. New York: W. W. Norton.

Rossiter, Clinton, ed. 1988. The Federalist Papers. New York: Penguin Mentor.

Storing, Herbert J. 1981. What the AntiFederalists Were For. Chicago: University of Chicago Press.

Tocqueville, Alexis. 1988. Democracy in America. Trans. George Lawrence and J. P. Mayer. New York: Harper Perennial.

Tocqueville, Alexis. 1990. Democracy in America, Vols. 1 and 2. Trans. Henry Reeve, Francis Bowen, and Phillips Bradley. New York: Vintage Classics.

Wasserman, Gary. 1991. The Basics of American Politics, 6th ed. New York: Harper Collins.

\section{About the Author}

Reid Cushman is a senior associate of the University of Virginia Health Policy Research Center. His current research assignments include the areas of medical informatics and outcomes/effectiveness analysis of medical protocols. He has taught introductory American government, political theory, and research methods as an assistant professor in the department of political science at nearby James Madison University. 